\title{
Federal Democratic Republic Nepal: Deepening Problems and Prospects
}

\section{Than Bahadur Chetri}

\begin{abstract}
Constructing federal democratic republic is a complex process. Both old and new democracies face different forms of challenges in building and maintaining, either internally or externally. Hence, this paper assesses the challenges in developing and maintaining democratic republic Nepal. With the help of secondary sources of information, it argues, building democracy in Nepal is undermined by foundational challenges and deepening challenges. Nepal, a closer analysis from the perspective of the constitution, geography and national wealth, rule of law, the nature of the party and their leaders, the prospect of a democratic republic is unclear.

Keywords: Bureaucracy, constitution, consolidated democracy, federalism, populist parties.
\end{abstract}

\section{Introduction}

This paper, aims to assess the state of Federal Democratic Republic and analyzes its prospects of development in Nepal. It argues, probability of sustaining democracy is dubious, the country lacks certain conditions which are necessary in maintaining democratic republic. Democracy is a form of government, a form of state, a form of society based on ethical values and a system of economy (Verma, 2008). Building democracy denotes establishment of electoral democracy and liberal democracy. It starts following the end of the autocratic regime. This transition to democracy is a dynamic and complex process. It may be 'consolidated', 'partially consolidated' or 'fully 
consolidated'. The matured democracy may de-consolidate over time. Deepening democracy is a process by which "a newly established democratic regime becomes sufficiently durable that a return to non democratic rule is no longer likely"(Gasioorowski and Power, 1998). It is a continuous process, denotes a change in political, economic, social arena over time.

Cultural theory argues that federal democracy is a Christian political system based on Bible thought and its practices, a close relation between "Western Christianity and democracy' (Huntington, 1991, 13, a). Take for instance, Catholic religion facilitatesto democratization whereas, "Islam hinders democracy" (Huntington; 1991, pp. 298-311,b). A long ago, Tocqueville said federalism does not rest on "either constitutional arrangement or laws, but on mores of society" (Mukherjee and Ramaswamy, 2005), what Anderson calls "constitutionalism and the rule of law" (Anderson, 2008, 12). To become and remain democratic 'mass values' in society are prime importance (Welzel and Inglehart, 2009.126-143). Consolidation of democracy success only after a change in political culture and absence of antidemocratic actors in the country (Diamond $(1999,67)$. The application of western democracy in different social, economic and cultural context brings conflict and controversy as well as war either internally or externally.).Hence, "federal is suitable for some countries and not for all"(Anderson, 2008, 12).

Pro democratic leaders or elites design democratic institutions and adhere democratic rules in their ambitions, as well as protect democracy, even in the periods of political or economic difficulties (Bunce, 2007;709). Frequent reversal of democracy is the absence of democratic political culture in "key elite groups and the general public" (Huntington; 1991; 18). According to Linz and Stepan's (1978), (in Problem of Democratic Transition 
and Consolidation: Southern Europe, Southern America and post Communist Europe) study shows that consolidation of democracy occurs at five 'arenas': "civil society, political society, rule of law, bureaucratic structure, and economic society", that is 'constitutional consolidation, representative consolidation, behavioral consolidation, the political culture consolidation' (Merkel, 2002; 79). The structural theory maintains that countries that had favorable conditions (economic, social and cultural) for democracy, the more well-to do a nation, the greater the chances that it will sustain democracy"(Lipset, 1959). The chances are slim in poor countries, "in rich countries, it has already occurred" (Huntington; 1991; 60). In the new and the post conflict societies, democracy is always weak, hence, it must strengthen "the bureaucracy; the democratic institutions and governance" (Diamond, 1999; 95). It is the 'country's economic system, its political culture and its constitutional arrangement' (Beetham, 1994; 157) facilitate deepening democracy.

The latest study says that all over the world democracy is in crisis, the younger generation and the wealthy people lack trust on democratic institutions and supports authoritarianism "Even in the long-established democratic regimes of Western Europe and the United States, attachment to democracy is weakening, particularly among younger citizens" (Mr. Mounk and Mr. Foa, 2017). Huntington (1996), noted the new danger to democracy is not from others but from the elected leaders and groups. Many social social scientists argue the rise of populism is the end of 'liberalism' and the rise of 'illiberal democracy' for example, Fareed Zakira in "The Rise of Illiberal Democracy").

In brief, both new and old democracies are facing different forms of challenges in developing and maintaining democratic republic. But the nature and forms of challenges differ from 
country to country (Diamond, 1999; 74). On the other hand, constructing and sustaining democracy in new and fragile societies, it is the most difficult task. They are inherently weak. If we want to know democracy and its prospects in any country we must look "political parties, elections, the role of elites, legislatures and bureaucracy" (Hood, 2004; 136).

Nepal is on the way of building federalism following the successful completion constitution writing and election of the all layers of the legislatures. On the basis of the above discussion, this paper aims to understand, the nature of the challenges and prospects in sustaining democracy in the context of Nepal.

\section{Methodology of the Study}

This paper is a qualitative study, based on secondary information, mainly collected from books, journals and the views that were published by various analysts in national dailies and weekly newspapers, fortnightly magazines. In addition to these, extensively internet based resources are used to argue. And it is appropriate to gain broad understanding of the situation and for authenticity.

It takes foundational challenges and deepening challenges as the independent variables and the dependent variable as consolidation of democracy. Political party and effective bureaucracy are taken as sub variables of foundational variables. Inclusion, rule of law and equality are the sub variables of deepening challenges. To explain the prospect of democracy, it takes constitution, geography, national wealth, republican virtues, populist parties as an independent variable. It takes the presence of weak values in these variables as the major challenges in maintaining and prospect of democracy. 


\section{Explain on Challenges in Deepening Democracy in}

\section{Nepal}

Nepal has completed seventy years in building democracy, but her efforts still revolve around writing and rewriting of the constitution and a change of ruling actors. From the constitutional perspective, we are still in the initial phase of the 1950 s period. The re-democratization process, which had started after 2006 was initiated with the aim of creating a new democracy, new economy and a new society, still face the same problem. It is dubious condition, whether the new democracy will be consolidated or not. The following section discusses the democratic practices under the democratic republic period.

\section{Foundational Challenges}

\section{(a) Party Organization and Party Behavior}

Political leaders need ideas and visions to govern the society, empowering the people and to provide justice. During the ten years of democratic exercise, the leaders of the major parties frequently visited the neighboring countries to gain and remain in power. Likewise, they kept themselves above the constitution and absolved themselves of any wrongdoing or unlawful activities. The elected legislators used private places as platforms for discussion of peace and constitution instead the constituent assembly, which is a big blow to the sovereign people. The constituent assembly dissolved without completing its task, it was a disrespect to people's mandate. The election of the constituent assembly was held twice, a rare event in the history of the world to write a constitution. Local government remained without the elected representatives for nearly twenty years. It deprived the general public to exercise their right to stand to choose their representatives, a natural right. 
The Council of Ministers promoted a culture of impunity. Many serious human rights violators are moving around openly without facing punishment. Laws, which favor the party have been amended overnight without following due procedures. They used the Supreme Court and President to fulfill their personal interests and protect the wrongdoers. The chief executive of the government, who is responsible for control of corruption, has constituted the largest cabinet in the history of the country, which comprises some corrupted people and criminals. It seems that our leaders are driven by the hunger for 'power, property and privileges'. They don't hesitated use of derogatory and harass remarks against leaders of rival parties, while addressing to their party cadres, without assessing the impacts and severity of the comments, use sentiment words to gain popularity.

Organizationally, political parties are running without a system of proper structure, a culture of rational choice decision making in the party is absent. As a result of this, political decisions in the party frequently bring conflicts and controversy, even disintegration of the party. Many of the party wings and their sister organizations do not have their office rooms to run day to day activity. Their cadres, used split bamboos to fulfill their demand and to keep people in the discipline, still lack adequate training and skills about how to govern the organization. Trade unions, student unions, teacher unions and other sister organizations of the parties, all lack intra-organization democracy. The leaders of these sister organizations lack ability to challenge party leaders, even malpractice occurs at the party. Democracy is for youths, the devolution of power to them is not working, and political parties have no provision of retirement of leaders.

In terms of recruitment and representation, political leaders compete with one another to protect criminals so as to increase 
the numbers of supporters of their respective party, the major parties have awarded the tickets to goons, business syndicate, fraud contractors and persons with criminal records who have just entered into the party on the basis of power and muscle disregarding their clean and honest cadre. When the electoral ambition is shattered, party leaders as well as cadre join rival parties just before the election period. Such as the personal secretary of the party's president and the district secretary of the party who spent years and decades in one party desert the mother party and has joined the oppositional party after he was denied election tickets. Former UML lawmaker quit his mother party and joined the Nepali Congress after he was granted an election ticket. Likewise 'former Deputy Speaker joined the UML just one day after the legislature parliament was dissolved'. Deputy Speaker of the Rastriya Prajatantra Party (Nepal) quit after the opposition party assured him to include in the list of proportional representatives. The chairman of the MJF (D) joined in mother party. Famous singer quit the Rastriya Prajatantra Party and joined the UML with a hope of getting the ticket, although, she was denied the ticket and revolted against the new party. A billionaire has been selected a PR candidate from the N.C, although he was a UML lawmaker under the PR category in the first constituent assembly. Such instances rarely occur in western countries. A leader of the Rastriya Janata Party-Nepal (RJP-N), who is also the president of Constituency no 2 in Saptri district, went hunger strike, demanding 'free and fair distribution of tickets for upcoming elections', as his party started 'distributing tickets to the nearest and dearest ones keeping deserving candidates out of contention'. The political leaders represent 'only the faction of a party or electoral constituency'. Financially, cash donation from businessmen, commission and wealth of the individual are the major source of income of the party, various studies have 
found that the income and expenditure of the national parties are improperly maintained and non-transparent. Recently, the Federation of Nepalese Commerce and Industry has appealed to the government to either stop 'unsystematic' donation collection during elections or legalize all forms of donations'.

Thus, the attitude and behavior of the political leaders and their supporters hardly match with the basic norms and values of the democratic system. An analysis of political parties of Nepal through the perspective of 'Minimum Standards for the Democratic Functioning of Political Parties' (2008), a criteria developed by the National Democratic Institute (NDI), shows that there is a wide gap between the criteria and Nepalese political parties. Dev Raj Dahal (2017) writes, in an article 'Rebuilding Civic Culture in Nepal', "the rise of strong leaders has weakened the institutional culture of the parties and their role of social integration". Politics needs a vision of the common good and support of values, whereas, our leaders have a narrow vision rooted in the periodic elections and the absence of democratic values.

\section{(b) Efficient and Effective Bureaucracy}

State employees, who work for the state are known as bureaucracy, operate under the rule of law and follows process and procedures and acts as a bridge between the people and the government. They provide a wide range of basic services to the people through different national and local agencies. Constitutional rights and human development are impossible to achieve without bureaucrats., in the words of democracies survives only after the existence of a "strong, technically competent, effective, efficient and responsive public service". Hamilton (2007; 3). A strong state institutions are essential in democratizing countries (Sodaro, 2001; 217). 
Weberian model of bureaucracy was introduced in the country following the end of the Rana regime with a view to establish impersonal rule in the administration as well as to bring an end of outdated malpractices. It is sad to say that the old practices and attitude and behavior are still in operation, although, they were the evils of previous regimes. The middle income people, state employees, are the agents of bending formal rules either this or that way. They are using government institutions as their ancestral property. It makes us confuse, whether the government offices are private or public offices. 'Poor service delivery and no service delivery in government offices is the outcome of personalization of state institutions. The Nepalese bureaucracy went further worse after the entry of trade unionism in 1990s. Coming under massive pressure of bureaucrats, the Government of Nepal has legalized unions affiliated to various parties in the pretext of securing their rights, instead of bringing it down. Currently, it is organized along the political parties and fragmented along the partisan lines. The number of CPNUML affiliated Nepal Civil Servants Employees Association is 44.39\% Nepali Congress affiliated Nepal Civil Servant Union consists of $34.16 \%$, Maoist- affiliated trade union is $10.57 \%$, Madheshi Civil Service Employee union is $6.87 \%$ and others are 3.4\% (Rawal, 2017). Such dozens of trade unions stills are in operation in all government departments, divisions and corporations and they are "enjoying their monthly pay without having to work for it" (Ghimire, 2016, Sept. 10). Another scholar, Dr Mukti Rijal (2016) a local governance expert, writes in an article entitled 'Revamping Bureaucracy', the government spends a huge amounts of national revenue on them, but their working style failed "to perform according to the expectation of the people". The chief of the government too has failed to "enforce and implement their instructions because of the tacit 
resistance and non-cooperation on the part of the bureaucracy". In the words of Shyam Mainali, the trade unions in Nepal have deviated from its track. They are working as "agents/brokers of affiliated political parties", gives 'undue pressure to ministry secretaries', instead of focusing their professional rights (based on Ghimire's report in Republica, national daily newspaper, 2016, Sep. 10). The recommendation of the political leaders' plays an important role in the promotion, transfer of government employees, teachers, high officials, justice. As a result of this, only the 'corrupt and politically-motivated officials' get an opportunity for advancement and other benefits (Pokharel, 2016, Aug, 20). Even the organizations and associations of journalists, who claim to make the fourth state, look like the sister organization and receives the order of the political parties. Dr Somlal Subedi blames for "unstable government". We (bureaucrats) are compelled to work with three governments in a year. Furthermore, as civil servants unnecessarily indulge in politics, public service delivery has become ineffective. However, we are bound to work" (based on Narayan Prasad Ghimire's report in Republica, 2016 Sep.10: entitled ..."Politics Ruins Public Service Delivery"). Taking the benefits of a weak state, donor agencies are active in policy formulation of the country, a handsome income for white men, in the name of strengthening democracy. The sad part is that these policies are neither discussed in the 'parliament nor at the societal level'.

State capture and administrative corruption' is common in Nepal According to Corruption Perception Index (2016), studies the levels of public sector corruption, ranks Nepal in $131^{\text {st }}$ position out of 175 countries reporting it as the third most corrupt country in south Asia. In 2004, the country was in $90^{\text {th }}$ position. Recently, Nagarik a national daily print media, published a survey conducted by the Nagarik Research Bureau (NRB) in 32 
districts of the country in 2016, which reports both "politicians and bureaucrats are the most corrupt. The police are the second most corrupt agency, followed by judges and lawyers in third position, non-governmental organizations (NGOs) in fourth and the corruption control agency itself in fifth place" (Republica, 2016, Jan, 26). Dr. Govinda K.C., a senior orthopedic surgeon at the Tribhuwan University Teaching Hospital (TUTH), has staged over a dozen hunger strikes against the corruption in the medical sector and demanding reform policies and investigation of the corrupted officials provides a glaring example of the state of corruption in Nepal.

Commission for Investigation of Abuse of Authority, is an apex constitutional body, has failed to control corruption in the country. In addition to it, the Government of Nepal appointed controversial bureaucrat as the head of the Chief Commission for Investigation of Abuse of Authority, despite wide criticism from all sides of his appointment, on the other hand, he also lacked require qualification, later he terrorized his opponents instead of maintaining good governance. Now-a-days, people opine that an independent judiciary is only on paper while the recruitment of party loyalists to judiciary has eroded judicial integrity. In this context, Former Chief Commissioner of the Commission for Investigation of Abuse of Authority, in an interview with Republica, opines "judicial is the least investigated area", so far there has not been any serious study on judicial corruption. He further adds, "Interestingly, not a single justice or judge has been prosecuted in charge of corruption in the country" (Republica, 2017; Sep, 21). The famous modern management principles, as developed by F.W Taylor and Max Weber, have still remained on paper. 


\section{Deepening Challenge \\ Inclusion, Rule of law and Equality}

Democratizing countries must improve the basic principle of democracy, inclusion, rule of law and equality. People must feel a better life in comparison to autocratic regime.. Weak state institutions neither establish justice nor promoted democracy, instead it produces haven of many ills. Women, an adult human being like man, constitute more than half of the population of the country. Their equal participation in the party or in the parliament is one of the indicators of the quality of democracy. The newly adopted constitution of the country aims "to build an egalitarian society founded on the proportional inclusive and participatory principles", it provides reserved seats for women and ethnic people at all levels. Despite, this provision, lack of rational choices in candidate selection in parties, women's political representation is poor, especially from the lower rank of the society. The concept of equality of opportunity is hijacked by the urban elites, a challenge to 'social integration'. Equality of opportunity for ordinary people is minimal in Nepal. The INSEC's report of various years shows that every year women and the children are the main victims of human rights violation. Right to academic freedom, the right to work and earn, right to movement obstructs by the cadres of political parties, associations, even by the student unions. Government is for fair allocation of economic resources to its citizens, whereas, our government distributes national budget to own constituency and those people who have access to power. In terms of government investment, it is mainly concentrated in only a few cities and the electoral constituency of the powerful leaders. Gender, marginalized people and remotes areas are again the victims of unequal distribution of government resources and economic opportunities. Right to basic amenities still remains a distant 
dream in various parts of the country. The rule of law data states, it is very poor in Nepal.

The present school education system is producing two types of citizens, even by the community school. The students of Nepali section belong to a poor income community and lower strata of the society. They feel inferior in front of the students, parents and teachers of English section community, when they cross each other inside the compound. Many state owned schools are inappropriate for quality study. School management committee is under the control of local politicians, to earn a good reputation in the society or to earn profit from the school, not for development of the school program. Private schools and colleges appears as a mint institution. The owners of private schools, colleges, banks, cooperatives, hydro power plants, hospitals and media are the political leaders, Education Minister, public schools' teachers and university professors. Middlemen and trade unions are practicing syndicate and cartel system in every sector. Similarly, the private sectors are running without unregulated and unsupervised, due to lure of commission by the bureaucrats. Laws are ineffective to protect and regulate consumer rights. Cooperatives, which are the foundation of democracy, better known as the third pillar of the national economy, are running against the prescribed norms and values. State building and nation building is in crisis due to absence of equality of opportunity and equity. Socialization by various agencies in Nepal is not compatible in sustaining democracy.

\section{Explain on Prospects of Federal Democratic Republic}

The country is on the way of institutionalizing federal democracy following the elections of the federal parliament, provincial parliaments and local governments. The leaders of the political parties are selling a sweet dream to the common people, after 
the successful completion of the election; it will end the chaos, political instability and multi polarity government. Nepal will enter into an era of economic development and a prosperous one within a few years. The above challenges can overcome, but, there are other factors that obstruct the prospects in developing and maintaining federal republic in Nepal are discussed below.

Modern constitution, is the foundation of democratic institutions and its practices, provides legitimacy of the regime and articulates collective goals and values, ends violent conflicts in society. It also helps in maintaining friendly relations with other countries. Construction of democracy starts with constitution writing, following the rejection, collapse or failure of an old political order. Constitution building is a complex process involving several consensuses; transitional leaders need consensus and trust among the political elites on the fundamental principle of the nation, to promote a common sense of belonging, national unity and harmony in the society. The prospects of constitutional democracy depend on how the actors drafted and implemented the constitution, nature of the political parties and how they view the world in his they live.

Internally, the Madhes based political parties are not happy with the constitution; they want fresh demarcation of federal units, an autonomous state in the whole tarai region. In the words of Anderson, a challenge to "a sense of identity with the whole community" (Anderson, 2008; 12). They even boycotted the first and second phases of the local polls, arguing that the constitution amendment bill was not endorsed by parliament. Finally, other major political parties brought them on board with various bargains and they participated in the third phase of election poll. Likewise, the former King, is not happy with the constitution, has been addressing the general public constantly 
through various media outlets expressing his worries regarding the deteriorating condition of the country, hinting subtly about his revival and leadership, which has garnered sympathy and support from people.

The non parliamentary force, led by Biplav which had split from the Communist party of Nepal Maoist Center, has rejected the new constitution and launched activities such as capturing lands of common people and asking the voters not participate in the coming polls. They have warned that "if they still go to the polling booths to cast votes, anything could happen". Recently, it is said that they have launched violent activities targeting the election campaign teams of the left alliance and Nepali congress, in various parts of the country to overthrow the constitution of Nepal 2015. Some of members of the campaign team have sustained serious injury. However, his party has not taken any responsibility of such violent activities. Both parliament and non-parliament forces are challenging the parliamentary form of government. He is following the same old revolutionary path, focuses on running the parallel government. How, the new government accommodates various demands in the constitution determines the stability of the country.

Externally, just two days before the promulgation of a new constitution, the Indian government sent envoy to pressurize the political leaders to put off the promulgation, but his request was not met. The three major political parties promulgated the constitution without addressing the demands of the Madhesi people. The new constitution was welcomed by the international community. Instead of welcoming it, India just 'just noted' it and imposed an undeclared economic blockade on Nepal which lasted for four and half months. Although the government of India denied it publicly. Professor S.D. Muni (2015) writes in 
an article on Economic \& Political Weekly, entitled "Nepal's New Constitution: towards Progress or Chaos", before the promulgating the new constitution, the Government of India invited to some prominent Nepali leaders in India and all of them assures India, all the major concern of the "marginalized groups would be accommodated" (Muni, 2015). But, it appeared an empty promise to Indian leaders and 'unresponsive to Indian concerns'. Muni further writes, Nepali leaders succeeded to accommodate the interest of 'China and the European Union, especially on religion and federalism, but not of India's concern. Hence, India proposed seven amendments in the constitution. Although, the relationship between the countries is normal, but the BJP led government, still strict to its old demands, wants the Nepali government to address several issues of the Madhes so as to make the constitution acceptable to all. In the eyes of CPN (UML) the demands of the Madhes based parties are anti national, how the new government will amend the constitution is yet to see in coming days. The politics of Nepal, since 1950s, is revolving around constitution writing and rewriting on. The constitution of Nepal failed to satisfy all, a politics of inclusion and exclusion is going on, for example, the King is excluded from the political game. Constitution amendment still remains a hot issue.

\section{National Wealth}

Democracy is functioning well in the USA because of "abundant natural resources and the availability of land" (Gellar, 2004). It has facilitated to the "development of egalitarian social structures" (Gellar, 2004). In the context of Nepal, she is a small hilly country, located between India and China. Nepal's national wealth is highly dependent on a single commodity, the agriculture. The agriculture sector occupies 28.9 percent of the 
Nepalese economy (GON/FM, 2016). According to international organization, agriculture provides "livelihoods for 68 percent of Nepal's population", currently, she is struggling "to produce an adequate supply of food for its citizens" (USAID, 2017, Nov 14). It is the outcome of non agricultural and urban concentrated population. It has depressed rural economies and increased widespread hunger and urban migration. Another study states "around 29 out of every 100 people living are poor in Nepal" (GoN/ Univ of Oxford 2018). Climate change putting additional problems like internal refugees within the nation, lack of water for daily needs. The poorer people will become the victims of food crisis in the future. The political elites may use food as a weapon to get legitimacy and remain in power. It brings political instability and security challenges.

"Americans are proud of their economic system" because, "it provides opportunities for all citizens to have good lives" (Conte 2001; 16). The 'prosperous economy' and 'quality of labour' is the main reason of success American democracy. The industrial sector in Nepal is not well developed, lack of superior education system in the country. Even after so many years of plans, the country still lacks core infrastructures, such as energy, transportation, health and education, to improve the economic condition and quality life of the population and to attract foreign investment. The exiting economic institutions are exclusive in nature. Slow implementation of national development projects is common, the politicians, bureaucrats and the contractors collude to get benefit. A look at the economic scenario, Nepal's ballooning trade deficit is increasing every year. Imports of petroleum products, chemical fertilizers and individual raw materials have been increasing continuously. In recent years, export of agricultural products is in decreasing trends and imports of vegetables and fruits have increased. Lately, the flow 
of remittance has fallen and the revenue collection has slowed down, the government is planning to control imports.

Federalism is an expensive system, it needs huge amounts to arrange infrastructures for dozens of departments in 7 provinces and provide facilities to the elected representatives, bureaucrats and security agencies. Internal revenues of these provinces are not self-sufficient nor does the overall national budget sustain the finances in all the provinces for a long time. It is estimated "at least Rs 820 billion would be required to run the federal" (GoN/MoF, 2017). Government cannot reduce the amount of grant to local units. The government will ultimately seek foreign aid. Consequently, Nepal will fall into a pit of poverty and debt trap as well as favorable conditions for more foreign influences. Federalism in Sudan failed to work due to failure of leadership, economic crisis, inflation and war.

\section{Republican Virtues}

Religion and democracy, both are interrelated and interdependent. Religion supplies mores and customs and manners that support democracy. On the basis of religion, democracy may be Hindu democracy, Islamic democracy, Christian democracy, Confucius democracy. The application federalism in non-democratic countries, it 'can be a sham" (Anderson; 2008). If you apply the Western/ Christian democracy in the Islamic state, it brings conflict. A war is going on between them in various parts of the world is the glaring example of it. The presence of ethnic and religious diversities and sit down and stand up order of the international community and their institutions in the weak is the root cause of conflict in any nation.

The April movement 2006 ended in an agreement between the King and the leaders of the major political parties. According to the agreement, the dissolved House of Representatives was 
reinstated by the king. Girija Prasad Koirala was appointed as the Prime Minister. Although, it was agreed that the constituent assembly will decide the fate of monarchy, but the self-nominated legislators of the reinstated House of Representatives declared the country republic 'prior to the election of the constituent assembly'. In this connection, Kul Bahadur Gurung, a senior leader of Nepali Congress, who had chaired the first meeting of the constitution Assembly, writes in his article entitled "Difficult to Amend" in Rising Nepal (a national daily).

I was the Speaker of the reinstated parliament when the parliament took these controversial decisions. When I told the party leaders to hold an extensive debate before taking a decision on these issues, almost all of them opposed it, stating that there was no need for it. When I let four MPs, including Chandra Bahadur Gurung, to express their views on the issue of monarchy by using my prerogative, they were hooted from the floor. Finally, the House abolished monarchy and declared Nepal a secular state without the people's consent. They did this when the interests of the leaders of the political parties matched (http://therisingnepal. org.np/news/14472.)

According to Grung, the country became secular of due to conspiracy of some leaders in the parliament; the leaders of the political parties abolished monarchy and declared Nepal a secular nation in 2007, although those were not the demands of the political movement of 2006. "No political document of the seven-party alliance had these demands". "Even the Maoists were not demanding this" and prevented him to take 'issue of monarchy and secularism to public before announcing Nepal as a secular republic' (http://therisingnepal.org.np/news/14472.) Besides Gurung, various leaders who were present in the 
initial House of Representatives, which took the decision of abolition of monarchy and opted secularism, have narrated at various instances about how the fast-paced decision might have been directed by foreign influences, raising serious concern regarding the approaches of political leaders and questioning the legitimacy of the decision to abolish monarchy and declare Nepal as a secular state.

As majority of people, on the other hand, have been following Hindu religion as their age-old tradition, most are not satisfied with the swift process with which political leaders excluded the religion and monarchy from the constitution without any discussion on the topic, violating the previous understanding. It has led them to believe that 'leaders have inserted anti people provision in the constitution' and 'existing republic may not be capable to establish peace in the country'. The pro Hindu party, the Rastriya Prajatantra Party (RPP) chairman led by Kamal Thapa, registered a constitutional amendment bill in the last parliament demands the provision on secularism, a European concept, be removed. He firmly stands on 'reinstatement of the Hindu nation and a constitutional monarchy', to him 'the concept of a secular state is fundamentally wrong, and federalism is not needed in Nepal".

Religious conversion is challenging the cultural, ethnic and religious diversities of Nepal, the beauty of the country. Many Hindus are worried about the drastic increase of the Christian. After the removal of the monarchy, the number of Christian population has dramatically increased (Tamang, 2016). According to World Christian Database (2016, Feb.3), which tracks global trends in Christianity, the country has become "one of the fastest-growing Christian populations in the world", conversion of low-caste Hindus are high in number (The 
Guardian"; 2017, August 15). The international community as well the Christian community are not happy with the new Civil Code', they are demanding right to conversion. They are providing huge amount the Christian community through NGOs in the name of strengthening democratic institutions, in reality, preaching Christianity and building church. An imbalance in the relationship between the Christian communities and other religions, it leads to conflicts. New and new challenges are emerging slowly. Democracy needs homogenous society to perform effectively, "the same rules do not produce the same results when inserted into different social structures and mores" (Tocqueville cited in Schmitter, 2004), is going to relevant in the context of Nepal.

\section{Nature of Political Parties}

The varieties of democracies around the world are the outcome of the nature of political parties. What type of political parties, we have during the time of democratization, what they think is an important question in a democracy. Nepal is a multi-religious, multi-lingual, multi- racial and multi-cultural country, we have multi ethnic people and they have countless, identities and beliefs. Likewise, Nepalese political parties also belief in multi ideals of democracy and its practices. The political parties failed to govern the nation in a democratic way in 1990s. Consequently, it gave the rise of the Maoists, radical left Populist Party. It launched a civil war that lasted (1996-2006). Since then, the domination of left parties has become stronger in Nepal. They actively participated in constitution making, the promulgation of the constitution through the constituent assembly was a big achievement to the leaders of the left parties. Commenting on the constitution, the Chairman of the CPN (Maoist Centre) had previously stated that the 'present constitution carries his party 
agenda'.

Currently, Nepal's parliamentary democracy is in crisis following the promulgation of the constitution. The leaders of the communist parties showed their hesitation to accept a parliamentary form of government. Just before the election, the two biggest communist parties CPN-UML and CPN- Maoist Center formed an electoral communist alliance to secure a two -third majority seats in the upcoming federal and provincial election and to merge all left parties.

Party alliance is not a new in Nepal. The present one has a long term vision in comparison to past alliance. They want amend of the constitution to introduce a directly elected. The Chairman of the CPN (Maoist Centre) expresses dissatisfaction with the constitution and "stresses on directly elected executive president". According to the national daily media report, Chairman of the CPN (Maoist Centre) said "in the last one decade 10 governments have changed" and in the last twentyseven years, twenty- six governments were formed which was the result of the prime ministerial system; the election of prime minister by the parliament is to be blamed for the political instability in the country". He further adds that the "time has come to make people aware of benefits of directly elected governance system which is itself in the welfare of the nation and citizens and is capable of controlling foreign interference in domestic affairs." "In the past, the NC and UML had 'withdrawn the idea of a directly elected president after they became the largest and second largest parties in the second Constituent Assembly election'. During the election campaign, the UML's Chairman said "once the communist alliance secures the thirds, we will amendment the constitution to introduce an elect executive for five years" (Spotlight, 2017; Nov.10). 
Presidential system is also a democracy, but it brings conflicts and controversy as well as war either internally or externally in weak and undemocratic ethnically diverse society. At one time, the UML Chairman openly opposed the amendment of the constitution as undemocratic, but now he is pursuing to amend it. Now, they are leading the government for five years, how the constitution amendment will take place in coming days is yet to see. Rise of populist parties in the parliament denotes the end of party democracy, change in party functions and erosion of democratic institutions. In the words of Lupu and Reidl (2012), such political leaders, create a new form of the regime which, according to Lupu and Reidl (2012), may produce 'regime uncertainty', 'economic uncertainty', and 'institutional uncertainty' instead of consolidation of democracy. The country will be a democratic republic of Nepal with the combination of the 'elements of authoritarianism with democracy'. Ecologically, a look at the regional level, the environment for democratic development is slim in south Asia. At the Northern side as it is dominated by autocratic populism, southern side by the religious populism, left populism is at the center and the rest countries are practicing autocracy. The prospect of democracy depends on the acceptance of key democratic features by the left populist parties.

\section{Conclusion}

The overall aim of this paper is to understand the challenges in maintaining and further strengthening democratic republic in Nepal. A federal democratic republic, denotes democratic institutions and democratic practices, depends on actors' role, virtues in society and structures of a particular country. A look through the pre-conditional approach, building and strengthening democratic republic in Nepal still remains a distant dream. The 
study identified that she lacks both foundational challenges and deepening challenges in maintaining democracy. Democratic Republic with political leaders is unthinkable. But, they are unable to govern the nation a democratic way and have been supplying wrong virtues and its practices. Democracy is for youths. In the context of Nepal, every year, thousand of thousand youths enter into the job market. But, they are compelled to leave the nation, prefers to go for abroad for their livelihood. Sad to say, these energetic youths return in coffins every day. The political leaders are not ready to hand over the powers to the youths, want to remain in power until s/he is not admitted to hospital. Power, property and privileges are prime importance for them.

The Weberian model of bureaucracy in the country is for strengthening democracy and establishing justice. The Middle class people, (consist of bureaucrats; employees of nonprofit organization; lawyer; medical workers, businessmen, academicians and so on), are the friends of democracy, are champion in bending and breaking the rules and regulations and constitution. The attitude and behavior of bureaucrats are more appropriate to the traditional political system.. In such a society, it is difficult to transplant the rule of law. Several study findings have noted "no rule of law, no democracy". Modern bureaucracy in Nepal, in this sense, is ill suited, it has lost its relevancy. Mal-governance and mal-redistribution has been contributing corruption everywhere. Constitutional bodies are not independent to carry out their functions independently due to politicization of state institutions. Similarly, the national corruption control agencies lack the power to crack down malpractices. In a democratic republic system, citizens enjoy a number of basic civil and political rights Human rights and liberties spelled out in the constitution are ineffective due to 
the behavior of bureaucrats. Access to human essentials still remains problematic. Equality of opportunity and equity, the political movements in Nepal were to end all kinds of injustice and inequality, but it is still in practices in various forms. Representational justice remains a distant dream for women of the lower section. The national cake is chunked by the urban elites.

A closer analysis from the perspective of federal political culture, the rule of law and nature of the party and their leaders as well as the fiscal federalism, the prospect of a democratic republic is not so bright. The agents of democracy derailment are challenging the existing regime from inside and outside the parliament. The populist parties, at now, are in power at all legislatures, federal, provincial and local, they will challenge the establish rules. On the other hand, the radical left populism is on the way of reviving the old method of revolution. In addition to these, the Republican leaders lack the habit of abiding constitutional culture. The passion for equality is very poor in practice. Taking benefits of weak state and vested interest leaders, some international agencies and countries are injecting the seeds of future conflicts to meet their interest in various parts of the country in the name of promoting democracy.

At the end, democracy is the solution of the autocratic regime, but the application of federalism in poor state capacity with weak economy growth brings lots of controversy and conflicts. Federalism, an attractive model, was introduced following the rise of populist leaders, lacks the virtues in leaders, which essential in maintaining democracy. Without strengthening rule of law and efficient bureaucracy for a democratic order, Nepal will remain Federal Democratic Republic only in paper. Democracy is for whom?, what kind of human resources we are 
producing from the educational institutions in converting the natural resources into goods, these are the question that needs further research. Thus, maintaining and further consolidating democratic republic, virtues in family, associations, educational institutions and leaders must develop.

\section{References}

Anderson, George (2008). Federalism: An Introduction. USA: Oxford University Press.

Beetham, D. (1994). Conditions for Democratic Consolidation In Review of African Political Economy. Volume 21, 1994 - Issue 60.

Bunce, Valerie (2000). Comparative Democratization: Big and Bouded generalization. Comparative Politics political Studies. Sep. Vol.33. No.6-7. pp 703-734.

Conte, Christopher (2001). Outline of the US Economy. US Department of State, Office of International Programs.

Dahal, Dev Raj (2017). Rebuilding Civic Culture In Nepal. The Rising Nepal (National Daily news paper). Available at http:// therisingnepal.org.np/news/20725.

Diamond, Larry (1999). Developing Democracy: Toward Consolidation. Baltimore: Johns Hopkins University Press.

Drèze, Jean and Sen, Amartya (2002). India and Participation. New Delhi : Oxford University.

Foa, Roberto Stefan and Mounk, Yascha (2017). The End of the Consolidation Paradigm. Available at http://roberto.foa.name/ FoaMounkEndofConsolidationParadigm.pdf. Retrieved on 5-11-2017.

Gasiorowski, Mark J. and Power, Timothy J. (1998). The Structural Determinants of Democratic Consolidation: Evidence from the Third World. In Comparative Political Studies. 31:6 (December) pp. 740-772. 
Gellar, Sheldon (2004). Tocquveillian Analytics: A Tool for understanding Democracy in Africa and the Non-western World. Available at: http://www.indiana.edu/ wow3/papers/ wow3_gellar.pdf. Retrived on 2018-1-4.

Ghimire, Narayan Prasad (2016). Bureaucracy intertwined with politics ruins public service delivery. Republica. National Daily Newspaper. September 10.

GoN/National Planning Commission and University of Oxford (2018). Nepal's Multidimensional Poverty Index: Analysis Towards Action. Nepal: Government of Nepal National Planning Commission. https://www.npc.gov.np/images/category/Nepal_ MPI.pdf .

Hamilton, Marry R. (2007). Democracy and Public Service. Richard C. Box edited Democracy and Public Administration. New Delhi; Prentice Hall of India. pp. 1-19.

Hood, Steven (2004). Political Development and Democratic Theory: Rethinking Comparative Politics. New Delhi; Prentice Hall of India.

Huntington, Samuel P. (1991). Democracy's Third wave. Journal of Democracy Vol.2. No.2 Spring.

Huntington, Samuel P. (1991). The Third Wave: Democratization in the Late Twentieth Century. University of Oklahoma Press.

Huntington, S.P. (1996). Democracy For The Long Haul. Journal of Democracy. 7.2 (1996) 3-13.

Lipset, S.M. (1959). Some Social Requisites of Democracy: Economic Development and Political Legitimacy. American Political Science Review. 53: 69-105.

Ministry of General Administration/UNDP (2014). The Nepal Civil Service and Re-structuring of the State. Available at http:// www.np.undp.org/content/dam/nepal/docs/projects/UNDP_NP_ PREPARE_the-nepal-civil-service-and-re-structuring-of-thestate.pdf. Accessed on 11-24-2017 
Mukherjee, Subrata and Sushila Ramaswamy (2005). Democracy in Theory and Practice. Delhi: Mcmillal India Ltd.

Muni,S.D. Nepal's New Constitution, towards progress of chaos?. Economic and Political Weekly, 3 October 2015, pp.15- 19.

Ministry of General Administration/UNDP (2014). The Nepal Civil Service and Re-structuring of the State. Available at http:// www.np.undp.org/content/dam/nepal/docs/projects/UNDP_NP PREPARE_the-nepal-civil-service-and-re-structuring-of-thestate.pdf. Accessed on 11-24-2017.

National Democratic Institute (NDI) (2008). Minimum Standards for the Democratic Functioning of Political Parties. Available at https://www.ndi.org/sites/default/files/2337_partynorms engpdf_07082008.pdf. Retrieved on 03 -12-2017 Retrieved on 7-11-2017.

Poudel,Keshab, (2017). Politics Same Leaders, Different System. Spotlight. (English New Magazine). Vol. 11, No. 08. Nov. 10. https://www.spotlightnepal.com/2017/11/10/politics-sameleaders-different-system/. Retrieved on 7-11-2017.

Preiss, Danielle (2016, 3 Feb). https://www.npr.org/sections/ goatsandsoda/2016/02/03/463965924/why-nepal-has-one-ofthe-worlds-fastest-growing-christian-populations. Retrieved on 7-11-2017.

Rawal, Ram Bahadur (2017). A Rajakat ko Akhada. Nepal (National Weekly Nepali Magazine) 26 Nov 2017 (Vol. 18, No.15). Retrieved on 7-11-2017.

Rija, Mukti (2017). Revamping Bureaucracy. Available at http:// therisingnepal.org.np/news/16788. Retrieved on 7-11-2017. Tamang, Ram Saran (2016). Christian Population Shoots Up Under Secular State. In Republica. Dec, $9^{\text {th. }}$

Sodaro, Michael Joesp (2001). Comparative Politics. A Global Introduction. New York: McGraw Hills.

Verma, S.L .(2008). Advance Modern Political Theory: Analysis and 
Technologies. New Delhi; Rawat publications.

Welzel, Christian and Inglehart, Ronald F (2009). Political Culture: Mass Beliefs and Values Change. In Christian W. Haepfer, Patrick Bernhagen, roald f. Inglehart and Christian Welzel edited.

Democratization. New York; Oxford Unive. Press.

www.tinepal.org (2016). Land Revenue offices most Corrupted: TI Study. Available at www.tinepal.org/land-revenue-offices-mostcorrupt-ti-nepal-study/. Accessed on 2017-8- 2. 